\title{
Percutaneous drainage in the treatment of Klebsiella pneumoniae lung abscess
}

\author{
E. W. J. CAMERON AND I. D. WHITTON \\ From the Thoracic Surgical Unit, Wentworth Hospital, P. B. Jacobs, Natal, South Africa
}

Cameron, E. W. J., and Whitton, I. D. (1977). Thorax, 32, 673-676. Percutaneous drainage in the treatment of Klebsiella pneumoniae lung abscess. Seven cases of lung abscess involving Klebsiella pneumoniae with or without other pathogens presented with gross expansion of the involved lobes or segments and severe clinical illness despite medical treatment. Operative management by rib resection and tube drainage was successful in each case, one of which was found to be an infected cryptococcoma. Postoperative bronchograms were made in six cases.

The current management of acute lung abscess is medical, but in the event of failure of medical treatment surgical intervention is required (Morris and Okies, 1974). There are three available surgical manoeuvres-bouginage of the involved bronchus to establish drainage of the abscess through the bronchi (Connors et al., 1975), tube drainage of the abscess through the chest wall (Monaldi, 1956), and pulmonary resection. It is recommended practice to resect the lobe or lung containing the abscess (Takaro, 1972) when medical management and bouginage have failed. This paper presents a series of seven patients with lung abscess treated by tube drainage, a common factor being the presence of Klebsiella pneumoniae in the abscess with gross expansion of the involved lobes or segments shown radiographically.

\section{The patients}

A clinical summary of the cases is given in Table 1. All patients were male except case 4 . Case 1 was Indian, case 6 European, and the others African. Pleuritic chest pain, cough, and fever were universal symptoms. Preoperative haemoglobin estimation showed levels of less than $10 \mathrm{~g} / \mathrm{dl}$ in cases $1,2,4$, and 7 , and these patients were transfused with blood. Other investigations included serial chest radiography and bacteriological examination of the sputum and lung aspirates. The pathogens cited in brackets in Table 1 were not demonstrated before drainage. Facilities for the proper isolation of anaerobes were not available during the period of this study, and the diagnosis of anaerobic infection was made from the putrid odour of the drained pus (Altemeier, 1938). In case 2 cryptococci were found on histological examination of the lung slough removed at drainage.

\section{Surgical management}

As a first step all patients were examined by bronchoscopy to ensure that the abscess was not secondary to a proximal abnormality, such as a tumour or retained foreign body, and to allow bouginage of the appropriate segmental or lobar bronchus. This technique failed to initiate drainage of the abscess in the four patients in whom it was attempted. In cases 4 and 5 distortion of the bronchial tree prevented bouginage, and it is possible that, had bouginage been successful, the resulting explosive discharge of pus would have soiled the other bronchi. Case 7 had a history of haemoptysis, and it was feared that bouginage might provoke endobronchial bleeding.

The reasons for undertaking drainage in this series of patients were various. In each, medical management based on antibiotics and physiotherapy had failed to diminish the symptoms, or the size of the radiographic opacity. In cases 3 to 7 marked clinical deterioration occurred during the phase of medical treatment, and cases 1 and 2 had courses of antibiotics lasting six weeks without evidence of clinical improvement. However, other factors also influenced the decision to drain, and the timing of the operation. In case 3 management of the abscess by resection implied pneumonectomy. Cases 4 and 5 experienced rapid progression of their illness with expansion of the abscess, resulting in mediastinal displacement, as shown in 
Table 1 Clinical summary of seven cases

\begin{tabular}{|c|c|c|c|c|c|c|c|}
\hline Case & Age & Previous history & Site of lesion & Bacteriology & Antibiotics & & $\begin{array}{l}\text { Duration medical } \\
\text { treatment }\end{array}$ \\
\hline 1 & 23 & $\begin{array}{l}\text { Pneumonia } 3 \mathrm{mth} \\
\text { previously }\end{array}$ & Apical RLL & $K$. pneumoniae & $\begin{array}{l}\text { Benzylpenicillin } \\
\text { Penicillin V } \\
\text { Tetracycline } \\
\text { Chloramphenicol }\end{array}$ & $\begin{array}{l}5 \mathrm{~d} \\
3 \mathrm{wk} \\
5 \mathrm{wk} \\
2 \mathrm{wk}\end{array}$ & $6 \mathrm{wk}$ \\
\hline 2 & 41 & $\begin{array}{l}\text { Pulmonary tuberculosis } \\
9 \text { yr previously }\end{array}$ & RUL & $\begin{array}{l}\text { K. pneumoniae } \\
\text { (cryptococcus) } \\
\text { (anaerobes) }\end{array}$ & $\begin{array}{l}\text { Streptomycin } \\
\text { Lincomycin } \\
\text { Chloramphenicol }\end{array}$ & $\begin{array}{l}4 \text { wk } \\
4 \text { wk } \\
2 \text { wk }\end{array}$ & $6 \mathrm{wk}$ \\
\hline 3 & 30 & Nil relevant & $\begin{array}{l}\text { Apical LLL } \\
\text { apicoposterior } \\
\text { LUL }\end{array}$ & $\begin{array}{l}\text { K. pneumoniae } \\
\text { D. pneumoniae }\end{array}$ & $\begin{array}{l}\text { Benzylpenicillin } \\
\text { Cephaloridine }\end{array}$ & $\begin{array}{l}7 \mathrm{~d} \\
3 \mathrm{wk}\end{array}$ & $3 \mathrm{wk}$ \\
\hline 4 & 24 & $\begin{array}{l}\text { Childbirth } 3 \text { wk } \\
\text { previously }\end{array}$ & RUL & $K$. pneumoniae & $\begin{array}{l}\text { Tetracycline } \\
\text { Chloramphenicol } \\
\text { Cephalexin }\end{array}$ & $\begin{array}{l}2 \mathrm{wk} \\
7 \mathrm{~d} \\
7 \mathrm{~d}\end{array}$ & $2 \mathrm{wk}$ \\
\hline 5 & 46 & Nil relevant & RUL & $K$. pneumoniae & $\begin{array}{l}\text { Streptomycin } \\
\text { Cephradine } \\
\text { Chloramphenicol }\end{array}$ & $\begin{array}{l}10 \mathrm{~d} \\
2 \mathrm{wk} \\
5 \mathrm{~d}\end{array}$ & 2 wk \\
\hline 6 & 18 & $\begin{array}{l}\text { Schizophrenic } \\
\text { drug addict }\end{array}$ & RUL & $\begin{array}{l}\text { K. pneumoniae } \\
\text { (anaerobes) }\end{array}$ & & & $10 \mathrm{~d}$ \\
\hline 7 & 34 & $\begin{array}{l}\text { Grand mal epilepsy; } \\
\text { lung abscess } 1 \mathrm{yr} \\
\text { previously in LLL }\end{array}$ & $\begin{array}{l}\text { RLL } \\
\text { LLL }\end{array}$ & $\begin{array}{l}\text { K. pneumoniae } \\
\text { E. coli } \\
\text { (anaerobes) }\end{array}$ & $\begin{array}{l}\text { Gentamicin } \\
\text { Cephradine } \\
\text { Tetracycline } \\
\text { Metronidazole }\end{array}$ & $\begin{array}{l}10 \mathrm{~d} \\
2 \mathrm{wk} \\
3 \mathrm{wk} \\
2 \mathrm{wk}\end{array}$ & 3 wk \\
\hline
\end{tabular}

RLL = right lower lobe;

RUL = right upper lobe

$L L L=$ left lower lobe;

LUL $=$ left upper lobe.

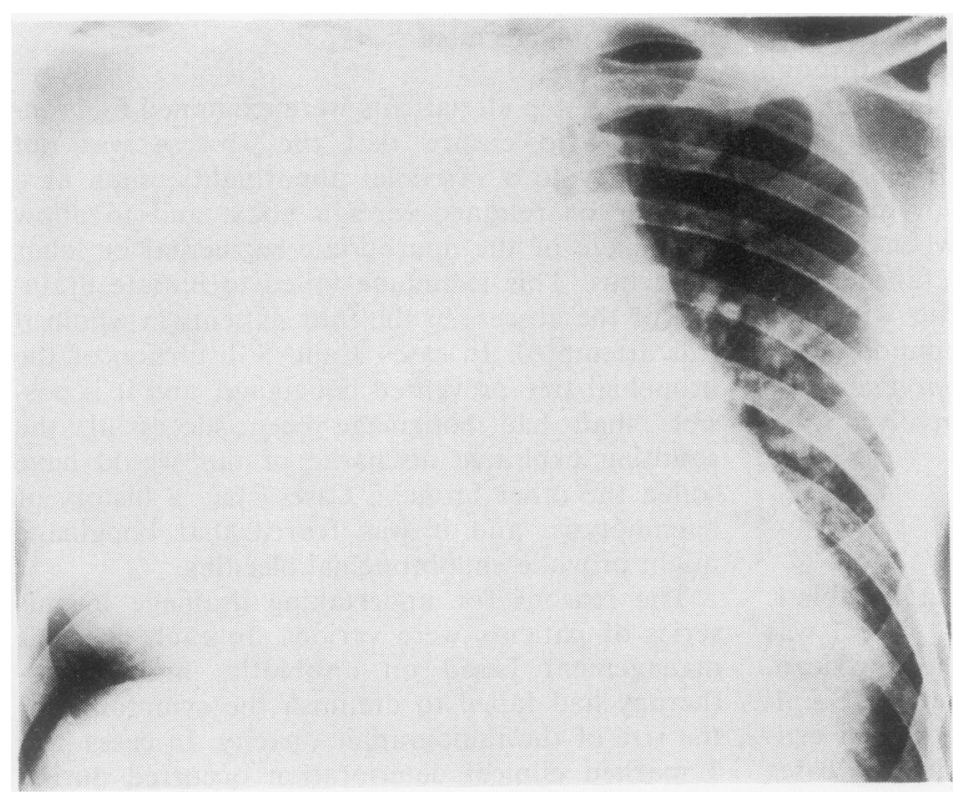

Fig. 1 Case 5. Chest radiograph showing abscess before drainage.

Figure 1. Case 6 would not tolerate hospital care: he refused to take an antibiotic regularly but agreed to operation. Case 7 presented with bilateral abscesses and was known to have had a previous lung abscess at the site of the present leftsided lesion.

Drainage was carried out under general anaesthesia with the appropriate main bronchus blocked

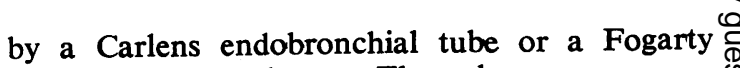
embolectomy catheter. The abscess was ap- $\stackrel{\mathcal{D}}{?}$ proached through the periosteal bed of a segment $\square$ of resected rib and fusion of the pleural layers in $\bar{O}$ the operative field was confirmed before entry $\mathbb{D}$ was made into the abscess. By resecting rib suffici- $\vec{\Phi}$ ent intercostal space was cleared to evacuate easily the abscess contents of pus and gangrenous lung, 
and to allow placing of a wide-bore tube in the resulting cavity. The wound was closed about the tube which was attached to an underwater seal drainage system if there was air leaking from the lung; otherwise open dependent drainage was instituted.

The results of operation were assessed both clinically and by bronchography. The immediate results of drainage were satisfactory; within 48 hours the patients were clinically well and without fever. The only postoperative complication occurred in case 4 in whom the abscess cavity refilled with blood clot which was removed through the drain wound on the third postoperative day. With this exception convalescence was in each case uneventful. The patients were discharged from hospital after removal of the drainage tube, healing of the operative wound, and disappearance of the cavity on the chest radiograph. In Table 2 duration of convalescence and the results of bronchography are listed. Only one patient, case 7, needed a further operation after discharge. Eight months after drainage his left-sided abscess recurred for the third time.

Table 2 Details of convalescence and results of bronchography

\begin{tabular}{|c|c|c|c|}
\hline Case & Convalescence & Bronchogram* & Result of bronchogram \\
\hline 1 & 19 days & 16 days & $\begin{array}{l}1 \mathrm{~cm} \text { cavity in apical } \\
\text { segment RLL }\end{array}$ \\
\hline 2 & 37 days & 35 days & Amputation of RUL \\
\hline 3 & 25 days & 24 days & Normal \\
\hline 4 & 10 days & 29 days & $\begin{array}{l}\text { Minimal dilatation of } \\
\text { anterior segment RUL }\end{array}$ \\
\hline $5 \dagger$ & 27 days & 21 days & $\begin{array}{l}\text { Shrunken RUL ectatic } \\
\text { anterior segment }\end{array}$ \\
\hline 6 & 10 days & & \\
\hline 7 & 25 days & 13 days & $\begin{array}{l}\text { Right side normal } \\
\text { Left side } 3 \mathrm{~cm} \text { cavity in } \\
\text { LLL }\end{array}$ \\
\hline
\end{tabular}

*Interval between drainage and bronchography.

†Bronchogram illustrated in Figure 2.

\section{Discussion}

Bartlett et al. (1974) have emphasised the role of anaerobes in the pathogenesis of lung abscess and have presented evidence that prolonged antibiotic therapy guided by accurate isolation of the pathogenic bacteria will heal lung abscesses. However, healing of an abscess depends also on evacuation of the contained pus and necrotic tissue followed by collapse of the abscess cavity. Lung abscesses can be expected to evacuate spontaneously through the bronchi. If evacuation fails to occur it is unreasonable to expect antibiotics to sterilise a lesion

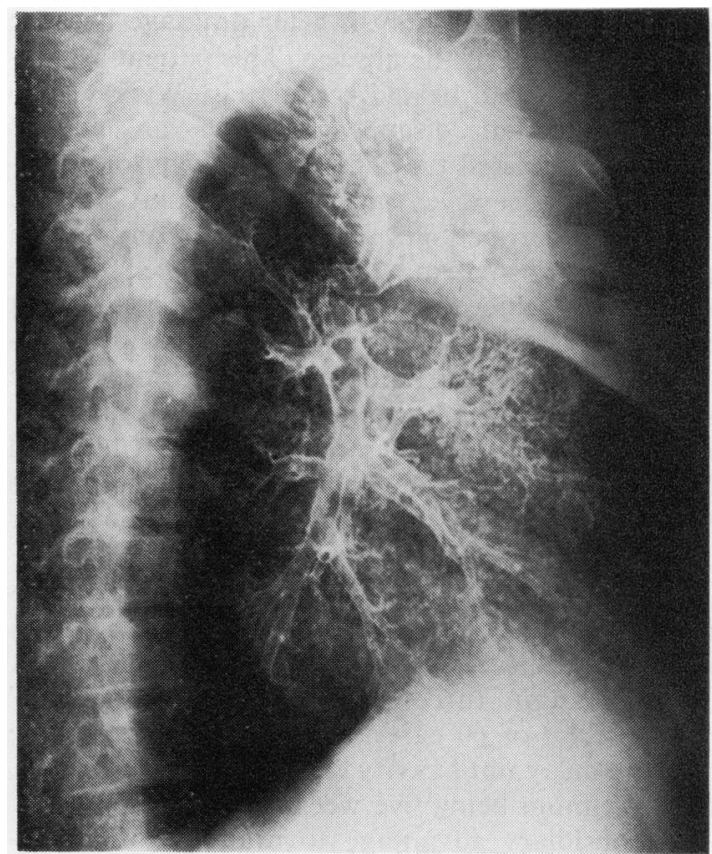

Fig. 2 Case 5. Bronchogram (right anterlor oblıque view) 21 days after drainage. See Table 2.

which has at its core a large volume of pus and gangrenous lung. In this series of patients spontaneous bronchial evacuation did not occur before the reasons for surgical intervention became compelling. The lesions themselves were large, the smallest measuring $11 \mathrm{~cm}$ in diameter on the posteroanterior chest radiograph, and each contained lung slough, a feature of Klebsiella pneumonia described by Knight et al. (1975).

Once the decision to operate had been made, the choice of drainage as opposed to resection was determined by the radiographic appearance of lobar or segmental expansion typical of Klebsiella pneumonia. The risks at thoracotomy of manipulating a grossly swollen lesion containing pus under tension, particularly in case 3 in whom pneumonectomy would have been required, contraindicated management by resection. The risk of abscess rupture, which was most alarming in cases 4 and 5 , was compounded by the presence of mediastinal shift. In these cases the ability to drain the abscess rapidly with the patient in a supine or semiFowler position was an advantage over the slow procedure of resection undertaken in the lateral position. General anaesthesia was used to give maximum control of the airway.

Retention of blood clot in case 4 was the only postoperative complication. In case 7 lobectomy 
was indicated nine months after drainage because of a recurrence of the abscess. This patient's rightsided abscess had healed completely. Weiss (1973) has noted that disappearance of an abscess cavity, as assessed on chest radiography or tomography, is deceptive since a cavity may still be evident on bronchography, and he found that a persistent parenchymal defect was not associated with clinical illness. Nevertheless there is no doubt that persistence of the cavity in case 7 was associated with a recurrence of the abscess. The sequence of initial drainage followed later by resection, which has been referred to by Chidi and Mendelsohn (1974), may be the safest course to follow in dealing surgically with this particular conformation of lung abscess.

Under medical treatment, cavity closure as judged on the chest radiograph, occurred in 11 weeks in the series of 26 cases of Bartlett et al. (1974), and in three months in $70 \%$ of Weiss' (1973) series of 60 cases. In the present series the average delay until cavity closure was three weeks, the maximum being five weeks.

A subsidiary advantage to drainage of an abscess is the opportunity for tissue biopsy. In case 2 the presence of cryptococci was not suspected since $K$. pneumoniae only had been isolated from sputum and lung aspirate. The diagnosis of a secondarily infected cryptococcoma was therefore made fortuitously on histological examination of the lung slough obtained at drainage. The patient made an undisturbed recovery after operation and was maintained on 5-fluorocytosine for three months. The postoperative bronchogram demonstrated autoamputation of the right upper lobe. With this exception a feature of the recovery of the patients has been the minimal loss of pulmonary parenchyma and the minor bronchial abnormality remaining as signs of initially gross lesions.
It is concluded that tube drainage should be considered in the operative management of lung abscesses, particularly if they are large and show evidence of tension within the abscess cavity.

\section{References}

Altemeier, W. A. (1938). The cause of the putrid odor of perforated appendicitis with peritonitis. Annals of Surgery, 107, 634-636.

Bartlett, J. G., Gorbach, S. L., Tally, F. P., and Finegold, S. M. (1974). Bacteriology and treatment of primary lung abscess. American Review of Respiratory Disease, 109, 510-518.

Chidi, C. C., and Mendelsohn, H. J. (1974). Lung abscess: a study of the results of treatment based on 90 consecutive cases. Journal of Thoracic and Cardiovascular Surgery, 68, 168-172.

Connors, J. P., Roper, C. L., and Ferguson, T. B. (1975). Transbronchial catheterization of pulmonary abscesses. Annals of Thoracic Surgery, 19, 254-260.

Knight, L., Fraser, R. G., and Robson, H. G. (1975). Massive pulmonary gangrene: a severe complication of Klebsiella pneumonia. Canadian Medical Association Journal, 112, 196-198.

Monaldi, V. (1956). Endocavitary aspiration in treatment of lung abscess. Diseases of the Chest, 29, 193-201.

Morris, J. F., and Okies, J. E. (1974). Enterococcal lung abscess: medical and surgical therapy. Chest, 65, 688-691.

Takaro, T. (1972). Lung abscess. In Textbook of Surgery, edited by D. C. Sabiston, Jr., pp. 1798-1801. Saunders, Philadelphia.

Weiss, W. (1973). Cavity behaviour in acute, primary, non-specific lung abscess. American Review of Respiratory Disease, 108, 1273-1275.

Requests for reprints to: E. Cameron, FRCSE, Department of Thoracic Surgery, Wentworth Hospital, P. B. Jacobs, Durban, Natal 4026, South Africa. 